\title{
Assessment of the molecular epidemiology of bovine ephemeral fever in Turkey
}

\author{
Feray Alkan ${ }^{1 *}$, Harun Albayrak², Mehmet O. Timurkan³, Emre Ozan ${ }^{4}$, \\ and Nuvit Coskun ${ }^{5}$ \\ ${ }^{\prime}$ Department of Virology, Faculty of Veterinary Medicine, University of Ankara, Ankara, Turkey \\ ${ }^{2}$ Department of Virology, Faculty of Veterinary Medicine, University of Ondokuz Mayis, Samsun, Turkey \\ ${ }^{3}$ Department of Virology, Faculty of Veterinary Medicine, University of Ataturk, Erzurum, Turkey \\ ${ }^{4}$ Veterinary Control Institute, Samsun, Turkey \\ ${ }^{5}$ Department of Virology, Faculty of Veterinary Medicine, University of Kafkas, Kars, Turkey
}

\begin{abstract}
ALKAN, F., H. AlBAYRAK, M. O. TIMURKAN, E. OZAN, N. COSKUN: Assessment of the molecular epidemiology of bovine ephemeral fever in Turkey. Vet. arhiv 87, 665-675, 2017.

\section{ABSTRACT}

In this study, the molecular epidemiology of bovine ephemeral fever in Turkey was investigated, on the basis of a comparison of the nucleotide sequences of the virus that caused the last outbreak, between early August and late November 2012, with those of the strains from the 1985 and 2008 outbreaks in Turkey, as well as BEF virus (BEFV) strains from Far Eastern countries, Israel and Australia. In the NJ analysis, the BEF viruses from the 1985 and 2008 outbreaks in Turkey were placed in the same cluster as the Israel isolates, while the 2012-outbreak BEFVs were placed in a different cluster, with the East Asian strains.
\end{abstract}

Key words: bovine ephemeral fever, molecular characterization, G gene, Turkey

\section{Introduction}

Bovine ephemeral fever virus (BEFV) belongs to the genus Ephemerovirus, which is a member of the family Rhabdoviridae. BEFV consists of a single-stranded RNA genome and 5 nonstructural proteins, including a nucleoprotein $(\mathrm{N})$, a polymerase-associated protein (P), a matrix protein (M), a large RNA-dependent RNA polymerase (L) and a surface glycoprotein $(\mathrm{G})$. Glycoprotein $\mathrm{G}$ includes four distinct antigenic sites (G1-G4) on its surface and is considered the major neutralising and protective antigen of BEFV (JOHAL et al., 2008; UREN et al., 1984; WALKER and KLEMENT, 2015).

\footnotetext{
*Corresponding author:

Feray Alkan, Prof. Dr., Department of Virology, Faculty of Veterinary Medicine, University of Ankara, 06110, Irfan Bastug Cad. Ziraat Mah., Ankara, Turkey, Phone: + 90312317 0317; E-mail: falkan@ankara.edu.tr
} 
Bovine ephemeral fever (BEF) infection was first reported in the mid-nineteenth century when the disease was first observed in East Africa (NANDI and NEGI, 1999). It has also been reported in Australia (FINLAISON et al., 2010; St GEORGE, 1997) and in most countries of Africa and Asia (BAKHSHESH and ABDOLLAHI, 2015; HSIEH et al., 2005; MOMTAZ et al., 2012; YERUHAM et al., 2002; ZAGHAWA et al., 2016) and Japan (KATO et al., 2009; NIWA et al., 2015; OGAWA, 1992). In Turkey, BEF infection was first recorded in 1985 (GIRGIN et al., 1986). After the first report, at least five outbreaks (in 1996, 1999, 2005, 2008 and 2012) were reported in the southern/south-eastern region, where the last outbreak was observed in 2012 (AZIZ-BOARON et al., 2012; OGUZOGLU et al., 2015; TONBAK et al., 2013).

The molecular characterisation of bovine ephemeral fever viruses (BEFVs) from Turkey was reported for the first time on the $\mathrm{G}$ gene that was partially characterised from the 2008 outbreak strain (AZIZ-BOARON et al., 2012). Recently, the sequencing of BEFVs from the 1985 and 2012 outbreaks have been reported (OGUZOGLU et al., 2015; TONBAK et al., 2013).

BEFV can survive the winter in insect vectors and/or new BEFV variants may travel from one country to another one by wind or the trade in livestock (YERUHAM et al., 2007; ZHENG and QIU, 2012). Vaccination for population immunity and prevention of transmission by a number of dipteral vectors have been the main important factors for the control of BEF infection (AZIZ-BOARON et al., 2012; AZIZ-BOARON et al., 2014).

In this paper, we aim to report and discuss the molecular characterization of BEFVs from various outbreaks, on the basis of our data/knowledge from the 2012 outbreak, and to report our opinion/suggestions regarding subsequent possible BEFV outbreaks in Turkey.

\section{Materials and methods}

History of 2012-BEF outbreak and samples. In early August 2012 BEF infection was clinically detected first in animals in Hatay $\left(36^{\circ} 12^{\prime} \mathrm{E}, 36^{\circ} 52^{\prime} \mathrm{N}\right)$. Then, the infection was detected in Gaziantep ( $\left.37^{\circ} 22^{\prime} \mathrm{E}, 37^{\circ} 05^{\prime} \mathrm{N}\right)$, Sanliurfa $\left(38^{\circ} 46^{\prime} \mathrm{E}, 37^{\circ} 08^{\prime} \mathrm{N}\right)$, Osmaniye $\left(36^{\circ} 14^{\prime} \mathrm{E}, 37^{\circ} 03^{\prime} \mathrm{N}\right)$, Adana $\left(35^{\circ} 18^{\prime} \mathrm{E}, 37^{\circ} 01^{\prime} \mathrm{N}\right)$, Kahramanmaras $\left(36^{\circ} 56^{\prime} \mathrm{E}, 37^{\circ} 35^{\prime} \mathrm{N}\right)$, Diyarbakir $\left(40^{\circ} 14^{\prime} \mathrm{E}, 37^{\circ} 55^{\prime} \mathrm{N}\right)$ and Mersin $\left(34^{\circ} 38^{\prime} \mathrm{E}, 36^{\circ} 48^{\prime} \mathrm{N}\right)$ provinces, located in the southern region of Turkey (Fig. 1).

Infected animals exhibit sudden onset of fever, stiffness, nasal and conjunctival discharge, breathing difficulties and death in the case of severe infections as quickly as within a few hours after the onset of clinical signs. Based on the information provided by the farmers and veterinarians, the mortality rate reached $25 \%$ in some herds.

In this study, a total of 27 whole blood samples were collected from cattle with clinical symptoms, housed in 3 different herds, and were tested for the partial sequences of the $G$ 
gene of the BEF virus using reverse transcriptase PCR (RT-PCR). Of them, 4 were from Herd I in Diyarbakır, and 14 and 9 were from Herd II and Herd III in Adana, respectively. The morbidity and mortality rates were approximately $90 \%$ and $15 \%$ respectively for the animals in Herd II (heifers, milk cows, calves and bulls), while the mortality rate reached approximately $26 \%$ for the heifers and adult cows, as reported by the herd manager.

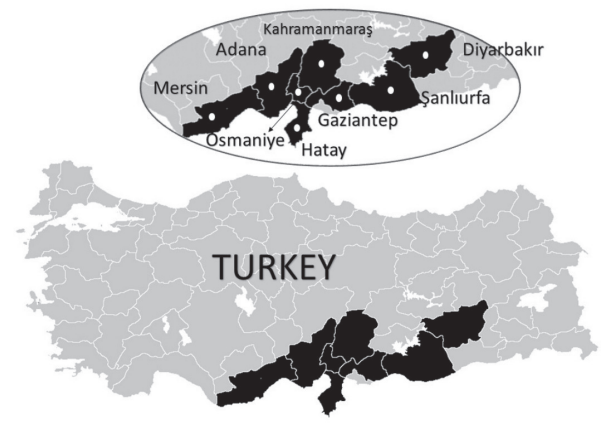

Fig. 1. Locations of BEFV outbreaks

Extraction, RT-PCR and sequencing. For the extraction of BEF genomic RNA from blood samples a commercial nucleic acid isolation kit (Roche, Germany) was used, as described in the manufacturer's manual. Then, the detection and characterisation based on the G gene of BEFV was performed with the oligonucleotide primers (BEF346F: 5'-TATTACCCTCCTGCCGGATGCTTT-3' and BEF1155R: 5'AGGTCTGTATTCGCACCAAGCTCT-3' located at nucleotide 346-369 and 11551132 , respectively) and the PCR procedure as reported elsewhere (AZIZ-BOARON et al., 2012). The PCR products, purified using a High Pure PCR Products Purification Kit (Roche Applied Sciences, Germany), were sequenced using an automatic sequence analyser (CEQ 8000; Beckman Coulter, Brea, CA, United States). Sequence editing and multiple alignments were performed with a bioedit software package, version 7.0.9.0 (HALL, 1999). Phylogenetic analysis (Neighbour-Joining) with bootstrap analysis (1000 replicates, 111 random seeds) and Kimura 2-parameter correction was conducted using the MEGA (Molecular Evolutionary Genetics Analysis) software package, version 5.0 (TAMURA et al., 2011).

\section{Results}

Of the 27 blood samples tested, 13 were found to be positive for BEFV by RT-PCR with amplicons of the expected size (809-bp in length). The positivity rates were $75 \%$ (3/4), 64.2\% (9/14) and 11.1\% (1/9) for Herds I, II and III, respectively. Four selected amplicons were partially sequenced. Our sequences (KC155353 to KC155355 and KC189910) were compared to the sequences of other BEFVs from Turkey and other 
F. Alkan et al.: Assessment of the molecular epidemiology of bovine ephemeral fever in Turkey

countries (Fig. 2). The percentages of nucleic acid identity and divergence are shown in Fig. 3. In Fig. 4, the predicted amino acid sequences of two neutralising epitopes (G2, position 168-189; G3, position 215-231 and 262-271) of the BEFVs from outbreaks in Turkey were compared with the sequences of the strains from the other countries, such as Far-Eastern countries, Israel, and also each other, using the Australian prototype strain BB7721.

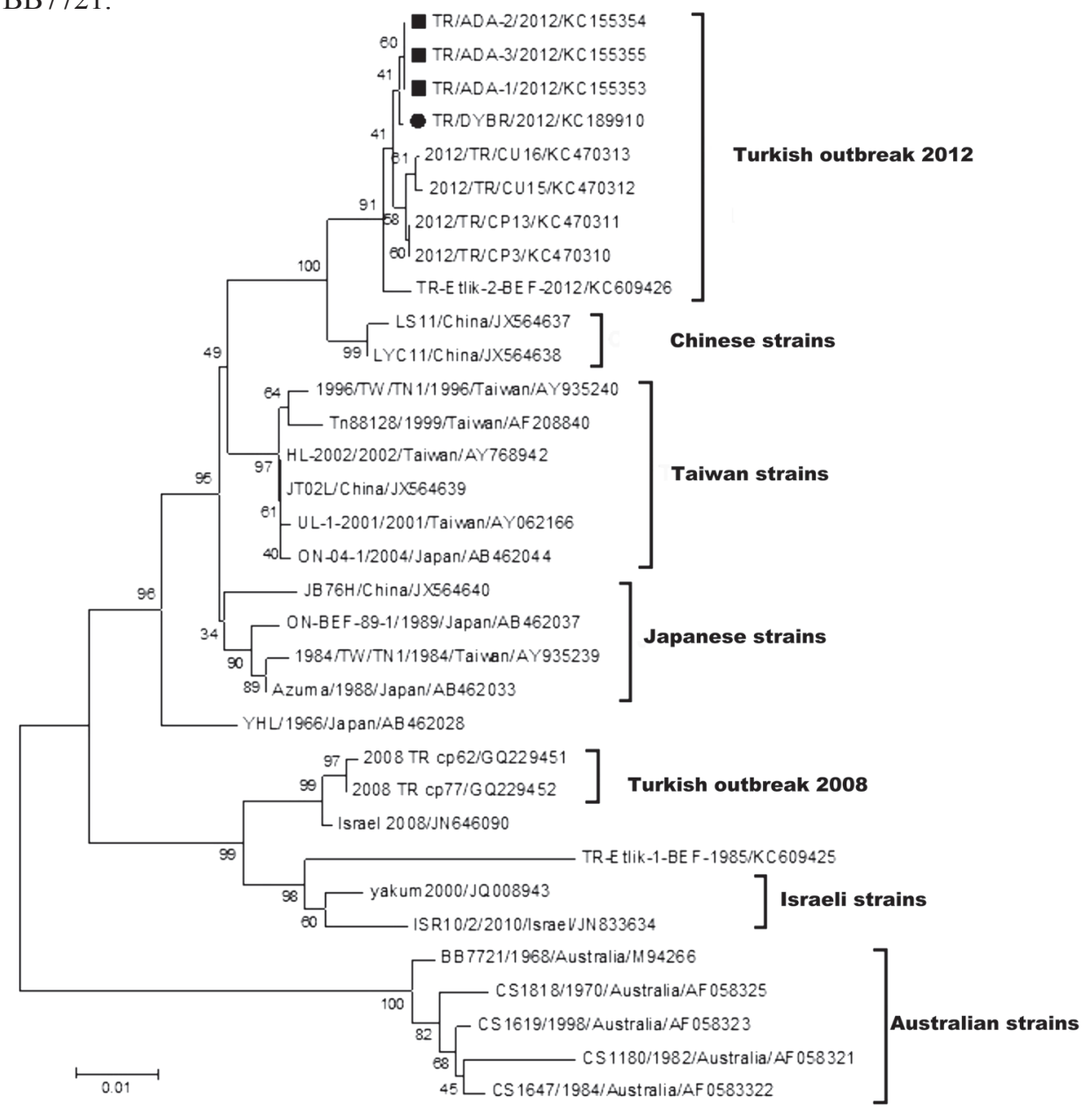

Fig. 2. Phylogenetic tree based on nucleotide sequences of the G gene of Turkish BEFV strains and BEFV strains from various countries. The accession numbers of the $\mathrm{G}$ gene region sequences (obtained from the GenBank database) used in this study are shown in the phylogenetic tree. 
F. Alkan et al.: Assessment of the molecular epidemiology of bovine ephemeral fever in Turkey

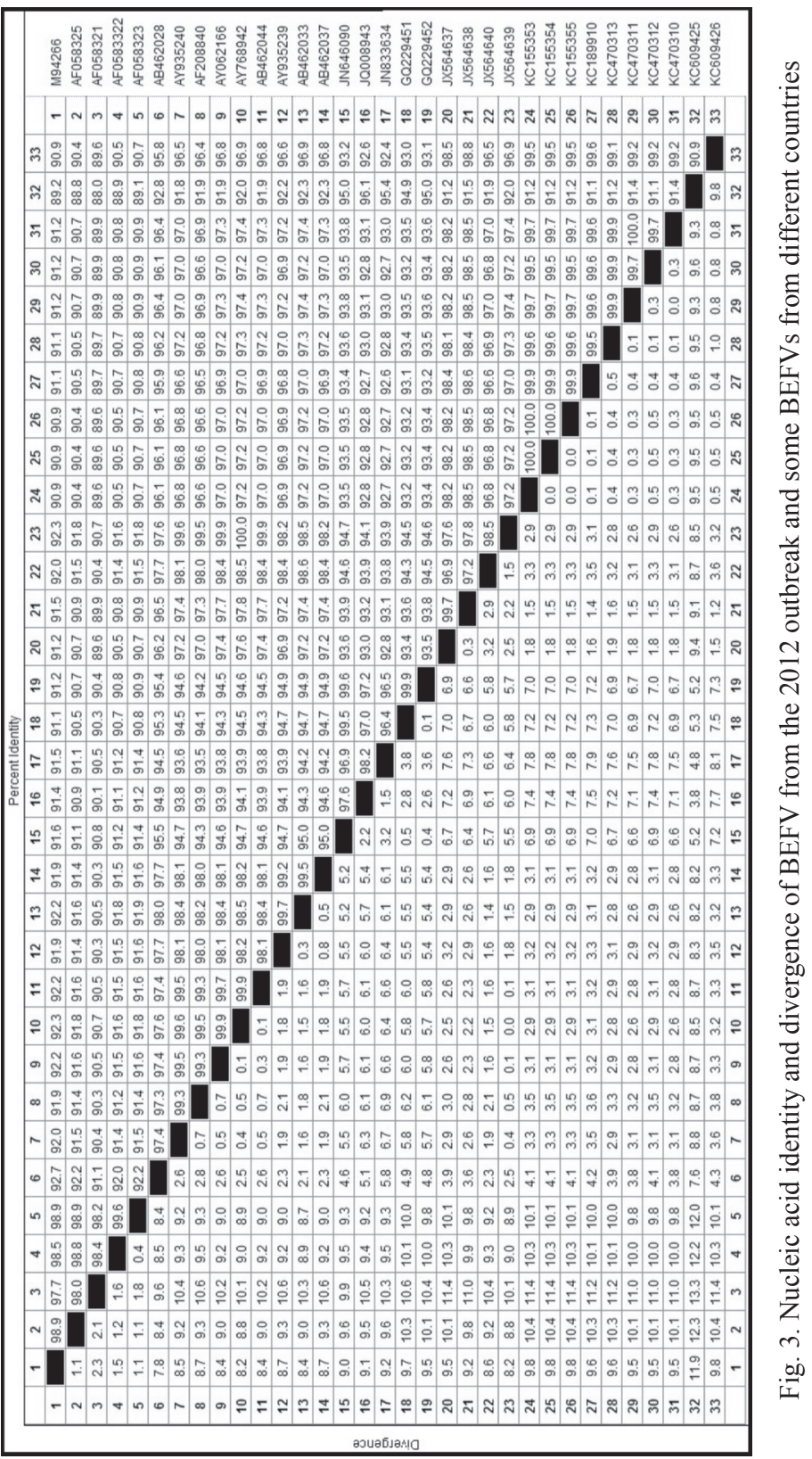


F. Alkan et al.: Assessment of the molecular epidemiology of bovine ephemeral fever in Turkey
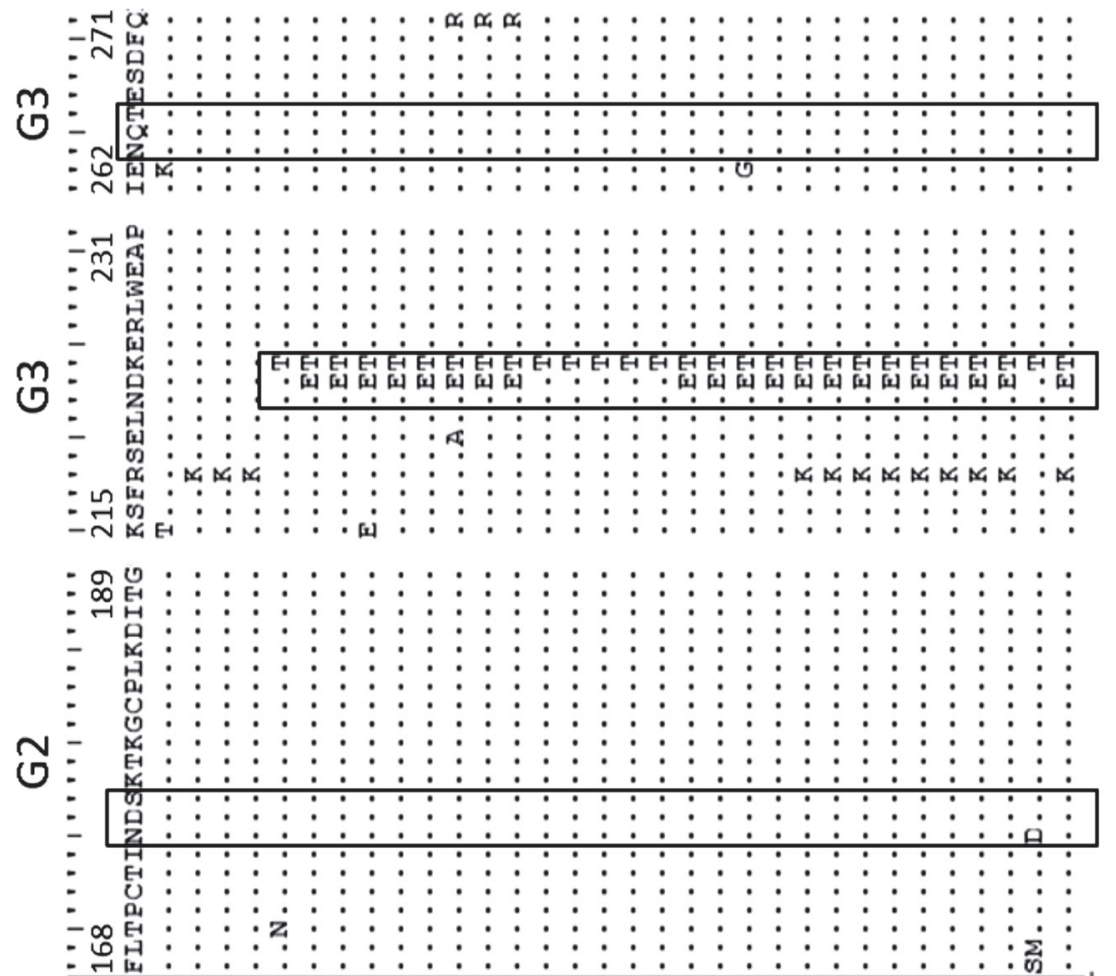




F. Alkan et al.: Assessment of the molecular epidemiology of bovine ephemeral fever in Turkey

\section{Discussion}

Glycoprotein $\mathrm{G}$, which is one of the nonstructural proteins of the virus includes four distinct antigenic sites (G1 - G4) on its surface, and is considered the major neutralising and protective antigen of BEFV (JOHAL et al., 2008; UREN et al., 1984). While one of the sites (G1) reacts only with anti-BEFV antibodies, the others (G2 - G4) show crossreactivity with sera against other related viruses (CYBINSKI et al., 1990; CYBINSKI et al., 1992; JOHAL et al., 2008; KONGSUWAN et al., 1998). The composition of these regions in the $\mathrm{G}$ gene sequences of the 2012-BEFVs differed from that of other field viruses from the 1985 and 2008 outbreaks in Turkey.

It was found that all BEFVs from the 2012 outbreak had some changes in terms of the $\mathrm{G} 3$ region amino acid (aa) sequences of the $\mathrm{G}$ gene at positions $218(\mathrm{R} \rightarrow \mathrm{K})$ similar to some Australian strains. Additionally, the changes at 223.aa. $(\mathrm{D} \rightarrow \mathrm{E})$ and 224.aa. $(\mathrm{K} \rightarrow \mathrm{T})$ were similar to the BEFVs from Far-Eastern countries. However, BEFVs (KC609425, GQ229451 and GQ229452) detected from the outbreaks in 1985 and 2008 showed only one change at 224.aa $(\mathrm{K} \rightarrow \mathrm{T})$ which was detected in the Israel strains from the 2000 and 2008 outbreaks, as well as the Japanese strain YHL (AB462028) (Fig. 4).

The similarities (94.9 - 95.0\%) between the BEFVs from the 1985 and 2008 outbreaks were higher than the identity index between BEFV-2012 and BEFV-1985 (90.9 - 91.4\%) and between BEFV-2012 and BEFV-2008 (93.0 - 93.6\%), according to Fig.3. On the other hand, the homology between the 2012 Turkish BEFVs and BEFVs from Far-Eastern countries was higher than the similarities between the 2012 BEFVs and BEFVs from the other countries, such as Australia and Israel (Fig. 3). The phylogenetic tree revealed that BEF viruses from the 1985 and 2008 outbreaks in Turkey were placed in the same cluster as the Israel isolates, while the 2012-outbreak BEFVs were placed in a different cluster with the East Asian strains, as shown in Fig. 2. Otherwise, the Iranian 2012/Sh strain of the virus circulating during the autumm of 2012 in Iran was also placed with the BEFV strain from the 2012 outbreak in Turkey, in the same branch as the Chinese 2011/ Shandong strain (BAKHSHESH and ABDOLLAHI, 2015).

In the 2012 outbreak, more severe clinical signs and higher morbidity and mortality rates were detected compared to previous outbreaks according to information provided by farmers and veterinarians. It is interesting that the BEFV strain that caused the 2012 outbreaks in Turkey was found to be similar to the virus that caused the 2011 outbreak in China, where the outbreak was also more severe than the outbreaks seen before (ZHENG and QIU, 2012). Similarly, TING et al. (2016) reported that the Taiwanese BEFVs obtained from the severe outbreak after October 2013 were grouped with the 2011-LYC11-China and 2011-Shandong-China, and 2012-CP-Turkey strains. Researchers (TING et al., 2016) suggested that these strains detected in Taiwan may come from China. 
It is known that BEFVs can survive the winter in insect vectors, and/or that new BEFV variants may travel from one country to another one by wind or trade in livestock (YERUHAM et al., 2007; ZHENG and QIU, 2012). Unfortunately, the origin of the BEFV that caused the last outbreak is not clear to us. In the past decade, a large number of animals were imported to our country from Australia, South American and European countries. According to the Australian livestock export industry, there is animal movement from Australia to Turkey and also from Australia to Far-Eastern countries such as China, and Middle Eastern countries such as Egypt, Israel and Saudi Arabia (http://www.mla.com. au/files/f1d10d44-8433-4955-bedd-a18900f09cfc/Australian-livestock-export-industrystatistical-review_2012.pdf.). It is thought that this situation should be examined in terms of the climatic conditions, vectors, molecular data, etc. in addition to animal movements in future studies.

Control of BEF infection mainly depends on vaccination and the prevention of transmission which is caused by a number of vectors (NANDI and NEGI, 1999; WALKER and KLEMENT, 2015). Recently, it has been reported that 2 of 3 major epizootics and $87 \%$ of regional outbreaks in Taiwan, where inactivated BEF vaccines have been applied, were associated with lower neutralizing antibody titers and immunity coverage (TING et al., 2014). Otherwise, the data on the efficacy of commercial vaccines in various formulations for the prevention of infection are not exactly clear (WALKER and KLEMENT, 2015). In Turkey, we do not have a vaccination programme or any data about the immunity status produced by the natural infection in the 2012 outbreak. Currently, there is no commercial BEFV vaccine imported to and/or produced in Turkey, but there is a pilot study reported by ERGANIS et al. (2010) on the production of BEF vaccine, using an isolate from outbreak-2008.

The size of the cattle population, the presence of high numbers of vectors, environmental conditions and rainfall levels that support the presence and the growth of vectors, etc. are important factors for infection by BEFV. It is known that the population dynamics of vectors in a particular region are influenced by climatic condition changes, thus the prevalence pattern of BEFV infection is affected similar to the transmission of Rift Valley Fever Virus (which is another arbovirus), as reported by XIAO et al., (2015). Additionally, the movement speed of livestock from one place to another increases the transmission of many other infections from an infected area to an uninfected area (AZIZBOARON et al., 2012; XIAO et al., 2015). Besides, there is religious festival which increases the animal movement in our country every year. The time of this festival shifts back ten days every year, so further festivals will be held in the spring and summer months in about two decades. Briefly, the possible increased vector population in the following two decades may be an important risk factor for BEF dynamics and also some other arbovirus infections, such as West Nile Virus, Akabane, Epizootic Hemorhagic Disease, etc. in Turkey. 
Briefly, BEFV infection will remain a threat with the potential to cause significant economic losses in Turkey and also European countries in the future, similar to occurrences of arbovirus infections, such as Bluetongue, Akabane, Schmallenberg virus, and West Nile virus. It may be said that a new BEF outbreak might be possible in the forthcoming two years (considering the time intervals between the outbreaks seen in 1996, 1999, 2005, 2008 and 2012). Possible causes for this are: decreased population immunity to natural infection from the previous outbreak, and the increased density of the vector population in the south-eastern region, where geographic and climatic conditions support the maintenance BEF vectors (DIK et al., 2014).

In conclusion, we believe that further studies will be helpful to understand the epidemiology of this infection and to determine convenient methods for prevention of the infection in Turkey, also in countries infected or countries posing risk of infection.

The preliminary findings of this study were presented at the $7^{\text {th }}$ Epizone Annual Meeting held during 1-4 October 2013, in Brussels, Belgium.

\section{References}

AZIZ-BOARON, O., Z. KLAUSNER, M. HASOKSUZ, J. SHENKAR, O. GAFNI, B. GELMAN, D. DAVID, E. KLEMENT (2012): Circulation of bovine ephemeral fever in the Middle EastStrong evidence for transmission by winds and animal transport. Vet. Microbiol. 158, 300-307.

AZIZ-BOARON, O., D. GLESER, H. YADIN, B. GELMAN, M. KEDMI, N. GALON, E. KLEMENT (2014): The protective effectiveness of an inactivated bovine ephemeral fever virus vaccine. Vet. Microbiol. 173, 1-8.

BAKHSHESH, M., D. ABDOLLAHI (2015): Bovine ephemeral fever in Iran: diagnosis, isolation and molecular characterisation. J. Arthropod-Borne Dis. 9,195-203.

CYBINSKI, D. H., P. J. WALKER, K. A. BYRNE, H. ZAKRZEWSKI (1990): Mapping of antigenic sites on the bovine ephemeral fever virus glycoprotein using monoclonal antibodies. J. Gen. Virol. 71, 2065-2072.

CYBINSKI, D. H., S. S. DAVIS, H. ZAKRZEWSKI (1992): Antigenic variation of the bovine ephemeral fever virus glycoprotein. Arch. Virol. 124, 211-224.

DIK, B., D. MUZ, M. N. MUZ, U. USLU (2014): The geographical distribution and first molecular analysis of Culicoides Latreille (Diptera: Ceratopogonidae) species in the Southern and Southeastern Turkey during the 2012 outbreak of bovine ephemeral fever. Parasitol. Res. 113, 4225-4232.

ERGANIS, O., S. YAVRU, Z. SAYIN, O. BULUT, M. HASOKSUZ, A. OZDARENDELI, A. BALEVI, K. KAV, O. AVCI, U. AKYEL, M. TOSLAK (2010): The development of vaccine for bovine ephemeral fever infection. Abstract book of $9^{\text {th }}$ National Congress of Veterinary Microbiology, 5-7 October, Nicosia, TRNC, p. 61. 
F. Alkan et al.: Assessment of the molecular epidemiology of bovine ephemeral fever in Turkey

FINLAISON, D. S., A. J. READ, P. D. KIRKLAND (2010): An epizootic of bovine ephemeral fever in New South Wales in 2008 associated with long-distance dispersal of vectors. Aust. Vet. J. 88, 301-306.

GIRGIN, H., A. D. YONGUC, A. AKCORA, E. AKSAK (1986): First outbreak of bovine ephemeral fever in Turkey (Türkiye'de ilk bovine ephemeral fever salgını). Etlik Veteriner Mikrobiyoloji Enstitüsü Dergisi 5, 5-12.

HALL, T. A. (1999): BioEdit: a user-friendly biological sequence alignment and analysis program for Windows 95/98/NT. Nuclecid Acids Symposium 41, 95-98.

HSIEH, Y. C., S. H. CHEN, C. C. CHOU, L. J. TING, C. ITAKURA, F. I. WANG (2005): Bovine ephemeral fever in Taiwan (2001-2002). J. Vet. Med. Sci. 67, 411-416.

JOHAL, J., K. GRESTY, K. KONGSUWAN, P. J. WALKER (2008): Antigenic characterization of bovine ephemeral fever rhabdovirus G and GNS glycoproteins expressed from recombinant baculoviruses. Arch. Virol. 153, 1637-1665.

KATO, T., M. AIZAWA, K. TAKAYOSHI, T. KOKUBA, T. YANASE, T. SHIRAFUKI, M. YAMAKAWA (2009): Phylogenetic relationships of the G gene sequence of bovine ephemeral fever virus isolated in Japan, Taiwan and Australia. Vet. Microbiol. 137, 217-223.

KONGSUWAN, K., D. H. CYBINSKI, J. COOPER, P. J. WALKER (1998): Location of neutralizing epitopes on the G protein of bovine ephemeral fever rhabdovirus. J. Gen. Virol. 79, 2573-2581.

MOMTAZ, H., S. NEJAT, M. MOAZENI, M. RIAHI (2012): Molecular epidemiology of bovine ephemeral fever virus in cattle and buffaloes in Iran. Rev. Méd. Vét. 163, 415-418.

NANDI, S., B. S. NEGI (1999): Bovine Ephemeral Fever: a review. Comp. Immunol. Microbiol. Infect. Dis. 22, 81-91.

NIWA, T., H. SHIRAFUJI, K. IKEMIYAGI, Y. NITTA, M. SUZUKI, T. KATO, T. YANASE (2015): Occurrence of bovine ephemeral fever in Okinawa Prefecture, Japan, in 2012 and develeoment of a reverse-transcription polymerase chain reaction assay to detect bovine ephemeral fever gene. J. Vet. Med. Sci. 77, 455-460.

OGAWA, T. (1992): Epidemiological investigation of bovine ephemeral fever outbreaks in Kyushu island in Japan during the fall of 1988. Prev. Vet. Med. 14, 69-76.

OGuzoglu, T. C., A. ERTURK, S. G. CIZMECI, B. T. KOC, Y. AKCA (2015): A report on bovine ephemeral fever virus in Turkey: Antigenic variations of different strains of BEFV in the 1985 and 2012 outbreaks using partial glycoprotein gene sequences. Transbound. Emerg. Dis. 62, e66-e70.

St GEORGE, T. D. (1997): Effective treatment of bovine ephemeral fever. Aust. Vet. J. 75, 221-222.

TAMURA, K., D. PETERSON, N. PETERSON, G. STECHER, M. NEI, S. KUMAR (2011): MEGA 5: Molecular Evolutionary Genetics Analysis using maximum likelihood, evolutionary distance, and maximum parsimony methods. Mol. Biol. Evol. 28, 2731-2739.

TING, L. J., M. S. LEE, S. H. LEE, H. J. TSAI, F. LEE (2014): Relationships of bovine ephemeral fever epizootics to population immunity and virus variation Vet. Microbiol. 173, 241-248. 
F. Alkan et al.: Assessment of the molecular epidemiology of bovine ephemeral fever in Turkey

TING L. J., M. S. LEE, Y. L. LIN., M. C. CHENG, F. LEE (2016): Invasion of exotic bovine ephemeral fever virus into Taiwan in 2013-2014. Vet. Microbiol. 182, 15-17.

TONBAK S., E. BERBER, M. D. YORUK, A. K. AZKUR, Z. PESTIL, H. BULUT (2013): A largescale outbreak of bovine ephemeral fever in Turkey, 2012. J. Vet. Med. Sci. 11, 1511-1514.

UREN, M. F., P. J. WALKER, H. ZAKRZEWSKI, T. D. St GEORGE, K. A. BYRNE (1984): Effective vaccination of cattle using the virion $G$ protein of bovine ephemeral fever virus as an antigen. Vaccine. 12, 845-850.

XIAO, Y., J. C. BEIER, R. S. CANTRELL, C. COSNER, D. L. DEANGELIS, S. RUAN (2015): Modelling the effects of seasonality and socioeconomic impact on the transmission of Rift Valley Fever virus. PLoS Negl. Trop. Dis. 9, e3388.

WALKER P. J., E, KLEMENT (2015): Epidemiology and control of bovine ephemeral fever. Vet. Res. 46, 124-141.

YERUHAM, L., Y. BRAVERMAN, H. YADIN, M. VAN HAM, D. CHAI, D. TIOMKIN, D. FRANK (2002): Epidemiological investigation of bovine ephemeral fever outbreak in Israel. Vet. Rec. 151, 117-121.

YERUHAM, I., Y. GUR, Y. BRAVERMAN (2007): Retrospective epidemiological investigation of an outbreak of bovine ephemeral fever in 1991 affecting dairy cattle herds on the Mediterranean coastal pain. Vet. J. 173, 190-193.

ZAGHAWA, A., F. M. T. HOUSAWI, A. AL-NAEEM, H. AL-NAKHLY, A. KAMR, R. TORIBIO (2016): Risk analysis and seroprevalence of bovine ephemeral fever virus in cattle in the Kingdom of Saudi Arabia. Trop. Anim. Health. Prod. 48, 487-492.

ZHENG, F., C. QIU (2012): Phylogenetic relationships of the glycoprotein gene of bovine ephemeral fever virus isolated from mainland China, Taiwan, Japan, Turkey, Israel and Australia. Virol. J. 9, 268-275.

AlKAN, F., H. AlbaYRAK, M. O. Timurkan, E. OZAN, N. COSKUN: Molekularna epizootiologija jednodnevne groznice goveda u Turskoj. Vet. arhiv 87, 665-675, 2017.

SAŽETAK

Istražena je molekularna epizootiologija jednodnevne groznice goveda u Turskoj. Nukleotidni slijed genoma virusa koji je uzrokovao posljednju epizootiju bolesti koja je u Turskoj harala od početka kolovoza do kraja studenoga 2012. godine bio je uspoređen s nukleotidnim sljedovima sojeva izdvojenih od 1985. do 2008. kao i sojeva iz dalekoistočnih zemalja, Izraela i Australije. Primjenom metode susjednog sparivanja, sojevi dokazani u Turskoj između 1985. i 2008. svrstani su u istu skupinu s izraelskim sojevima, dok su sojevi iz 2012. pripadali istočnoazijskoj skupini.

Ključne riječi: jednodnevna groznica goveda, molekularna analiza, gen G, Turska 
